\title{
The endolysins of bacteriophages CMP1 and CN77 are specific for the lysis of Clavibacter michiganensis strains
}

\author{
Johannes Wittmann, Rudolf Eichenlaub and Brigitte Dreiseikelmann \\ Department of Microbiology/Genetechnology, Faculty of Biology, University of Bielefeld, \\ Universitaetsstr. 25, 33615 Bielefeld, Germany
}

Correspondence

Brigitte Dreiseikelmann

b.dreiseikelmann@uni-bielefeld.

de

Received 16 December 2009

Revised 5 May 2010

Accepted 6 May 2010

\begin{abstract}
Putative endolysin genes of bacteriophages CMP1 and CN77, which infect Clavibacter michiganensis subsp. michiganensis and C. michiganensis subsp. nebraskensis, respectively, were cloned and expressed in Escherichia coli. The His-tagged endolysin of CMP1 consists of 306 amino acids and has a calculated molecular mass of $34.8 \mathrm{kDa}$, while the His-tagged endolysin of CN77 has 290 amino acids with a molecular mass of $31.9 \mathrm{kDa}$. The proteins were purified and their bacteriolytic activity was demonstrated. The bacteriolytic activity of both enzymes showed a host range which was limited to the respective C. michiganensis subspecies and did not affect other bacteria, even those closely related to Clavibacter. Due to the high specificity of the CMP1 and CN77 endolysins they may be useful tools for biocontrol of plantpathogenic C. michiganensis without affecting other bacteria in the soil.
\end{abstract}

\section{INTRODUCTION}

The genus Clavibacter is a member of the Microbacteriaceae, a group of Gram-positive bacteria of high $\mathrm{G}+\mathrm{C}$ content that can be distinguished from other groups among the Actinobacteria by the unusual peptidoglycan type B and unsaturated respiratory menaquinones (Park et al., 1993). The plant-pathogenic bacterium Clavibacter michiganensis, the only species in the genus Clavibacter, includes five subspecies which are defined with respect to their host plants: subsp. michiganensis (Solanum lycopersicum), nebraskensis (Zea mays), insidiosus (Medicago sativa), tessellarius (Tritium aestivum) and sepedonicus (Solanum tuberosum) (Davis et al., 1984; Lee et al., 1997; Eichenlaub et al., 2007).

C. michiganensis subsp. michiganensis $(\mathrm{Cmm})$ causes bacterial wilt and canker, the most important bacterial disease of tomato, which results in severe crop failures in all tomato-growing areas worldwide (Strider, 1969). Control of Cmm infections is difficult because there are neither resistant tomato cultivars nor effective chemicalbased approaches available. Thus, the spread of $\mathrm{Cmm}$

Abbreviations: Cmm, Clavibacter michiganensis subsp. michiganensis; $\mathrm{Cmn}$, C. michiganensis subsp. nebraskensis; Cmt, C. michiganensis subsp. tessellarius; DAB, diaminobutyric acid; NTA, nitrilotriacetic acid.

The GenBank/EMBL/DDBJ accession numbers for the complete genome sequence of phage CMP1 and for the CN77 Smal restriction fragment are GQ241246 and GU097882, respectively.

A supplementary table, showing the results of a lysis assay with CMP1 endolysin on different Microbacteriaceae strains, is available with the online version of this paper. infections can only be limited by using certified seeds, strict hygiene measures and eradication of infected plants.

Based on problems with antibiotic resistance of human and animal pathogenic bacteria and on the lack of effective antibacterial compounds for disease control in plants, the interest in bacteriophages for therapy of bacterial infections has increased during the last few years. To date, there are many examples of the application of bacteriophages in disease control of humans, animals and plants (Sulakvelidze \& Barrow, 2005; Sulakvelidze \& Kutter, 2005; Jones et al., 2007). In agriculture, phages have been successfully used, e.g. against soft rot and fire blight caused by Erwinia spp. (Eayre et al., 1990; Schnabel et al., 1998), tomato bacterial spot caused by Xanthomonas spp. (Balogh \& Jones, 2003) and tobacco bacterial wilt caused by Ralstonia solanacearum (Tanaka et al., 1990).

Disease control with the help of bacteriophages can be achieved either with the bacteriophages themselves or with phage-encoded bactericidal enzymes (Parisien et al., 2008). Since it is difficult to treat large agricultural areas with an enzyme formula it seems more suitable to use the genes for lytic enzymes of bacteriophages for the generation of transgenic plants. The endolysins of tailed bacteriophages, which are synthesized in infected bacteria late in the lytic cycle for the release of the progeny phages, are good candidates for this purpose and have a high potential for application in therapy and disease control, because of their diversity and specificity (Fischetti, 2008; Loessner, 2005). A high efficiency in lysis of the pathogenic bacteria and specificity for the host are prerequisites for an application in the prevention and/or treatment of bacterial infections. 
The search for an endolysin specific for $\mathrm{Cmm}$ seems promising because the peptidoglycan type B $2 \gamma$ is not very frequent among bacteria (Schleifer \& Kandler, 1972). The type $\mathrm{B} 2 \gamma$ peptidoglycan is defined by a cross-linkage between positions 2 and 4 of the peptide subunits (B), a D-diamino acid in the interpeptide bridge (B2) and Ldiaminobutyric acid (DAB) at position 3 of the peptide subunit $(\mathrm{B} 2 \gamma)$. A further advantage is that Gram-positive bacteria are easy to lyse by an enzyme from the outside since they have no outer membrane.

This study mainly focuses on the endolysin of bacteriophage CMP1 of Cmm first described by Echandi \& Sun (1973). The endolysin of CN77, a phage with the host C. michiganensis subsp. nebraskensis (Cmn) (Cook \& Katznelson, 1960; Shirako et al., 1986; Vidaver et al., 1981), was included in the study in order to increase the chance of finding a highly specific enzyme.

\section{METHODS}

Bacterial strains and phages. Bacteriophage CMP1 was a gift from E. Echandi, North Carolina State University (Echandi \& Sun, 1973). Bacteriophage CN77 was from the Felix D'Herelle Reference Center for Bacterial Viruses, Universite Laval (Canada). For the propagation of the phages, the host strains Cmm NCPPB3123 and Cmn Her1088 (Université Laval) were incubated with shaking in TBY (per litre: $10 \mathrm{~g}$ tryptone, 5 g yeast extract, $5 \mathrm{~g} \mathrm{NaCl}, \mathrm{pH} 7.5)$ at $26{ }^{\circ} \mathrm{C}$ until a titre of $3 \times 10^{8}$ c.f.u. $\mathrm{ml}^{-1}$ was reached. After infection with phages at an m.o.i. of 0.1 , incubation was continued at room temperature without shaking until lysis was complete (about 15-20 h). The lysate was cleared by centrifugation.

Expression of the endolysin genes was done in Escherichia coli ArcticExpress [E. coli $\mathrm{B}, \mathrm{F}^{-}$, ompT, $h s d S_{B}$, gal, $\lambda(\mathrm{DE} 3)$, endA Hte $\left.\left(c p n 10, c p n 60, \mathrm{Gent}^{\mathrm{r}}\right)\right]$ (Stratagene).

The Microbacteriaceae and further Gram-positive bacteria used for the activity assays are listed in Supplementary Table S1. The strains $\mathrm{Cmm}$ 2-7, 4-4, 9-4, S-5 and S-7 were isolated from infected tomato plants from the island of Reichenau (Germany); the strains Cmm 18, 24, 42, 48,56 and 64 were a gift from S. Manulis-Sasson and were isolated at different places in Israel (Volcani Center, Bet Dagan, Israel; Kleitman et al., 2008). The C. michiganensis subspecies were from the National Collection of Plant Pathogenic Bacteria (NCPPB), Laboratorium voor Microbiologie (LMG; Ghent, Belgium) and ATCC collections.

Purification of phages and phage DNA. Purification of the phages by $\mathrm{CsCl}$ gradient centrifugation and of the DNAs by phenol extraction was done as previously described (Beilstein \& Dreiseikelmann, 2006).

PCR amplification and cloning of the endolysin genes. After determination of the phage DNA sequences, primers could be generated for the amplification of the lys genes. The forward primers carried an NdeI recognition site and the reverse primers a XhoI recognition site at the $5^{\prime}$ ends. The PCR mixtures contained phage DNA as target, dNTPs, polymerase Pwo (Peqlab), the corresponding reaction buffer (Peqlab) and the primer pairs 5'-CGCATATGTCCGAGAATCTTAAC-3' and 5'-CCTCGAGTTTCTTATCGGGGG$3^{\prime}$ for the CMP1 endolysin gene amplification, and 5'-CGCATATGGGCTACTGGGGGT-3' and 5'-CGCTCGAGTGCGGCAGCCCG-3' for the CN77 gene amplification. Amplification was done with a gradient cycler (Stratagene). PCR conditions were one cycle of $10 \mathrm{~min}$ at $95{ }^{\circ} \mathrm{C}$, followed by 35 cycles of $90 \mathrm{~s}$ at $95{ }^{\circ} \mathrm{C}, 90 \mathrm{~s}$ at an annealing temperature between 50 and $66{ }^{\circ} \mathrm{C}, 90 \mathrm{~s}$ at $72{ }^{\circ} \mathrm{C}$, and one final cycle of $10 \mathrm{~min}$ incubation at $72{ }^{\circ} \mathrm{C}$. The PCR products were hydrolysed with restriction endonucleases $N d e \mathrm{I}$ and $\mathrm{XhoI}$ and ligated with pSCodon1.2 (Eurogentec) digested with the same enzymes. The main features of this vector are a T7 promoter, six his codons (for a Cterminal His-tag) and genes for five rare tRNAs. E. coli ArcticExpress (Stratagene) was transformed with the hybrid pSCodon1.2_lys plasmids by the $\mathrm{CaCl}_{2}$ method. Selection of transformed cells was done on TBY agar plates with ampicillin $\left(150 \mu \mathrm{g} \mathrm{ml}^{-1}\right)$ and gentamicin $\left(10 \mu \mathrm{g} \mathrm{ml}^{-1}\right)$.

Expression and identification of the endolysins. $E$. coli ArcticExpress pSCodon1.2_lys_CMP1 or pSCodon1.2_lys_CN77 was grown in TBY medium with ampicillin $\left(150 \mu \mathrm{g} \mathrm{ml}^{-1}\right)$ and gentamicin $\left(10 \mu \mathrm{g} \mathrm{ml}^{-1}\right)$ at $26^{\circ} \mathrm{C}$ to a titre of about $4 \times 10^{8}$ c.f.u. $\mathrm{ml}^{-1}$. The culture was cooled down. After addition of $1 \mathrm{mM}$ IPTG, incubation was continued with shaking at $12{ }^{\circ} \mathrm{C}$ for $15 \mathrm{~h}$. Overproduction of endolysin was monitored by SDS-PAGE of total cell protein recovered after boiling of the cells in cracking buffer (Laemmli, 1970; Lanka \& Barth, 1981). For the identification of soluble proteins, supernatants of centrifuged French Press extracts were used for electrophoresis.

Isolation of the endolysin. Sedimented cells from a $200 \mathrm{ml}$ induced culture were frozen at $-80{ }^{\circ} \mathrm{C}$. After thawing, the cells were suspended in $3 \mathrm{ml}$ buffer A $(50 \mathrm{mM}$ sodium phosphate buffer, $\mathrm{pH}$ 7.8, $300 \mathrm{mM} \mathrm{NaCl}, 10 \mathrm{mM} \beta$-mercaptoethanol). Cells were lysed by three passages through the French pressure cell at $124200 \mathrm{kPa}$. The lysate was cleared by centrifugation for $30 \mathrm{~min}$ at $25000 \mathrm{~g}$. The supernatant was centrifuged again and applied to a Ni-nitrilotriacetic acid (NTA; Qiagen) column (bed volume $0.4 \mathrm{ml}$ ) equilibrated with buffer A. After washing with buffer A and buffer A with $20 \mathrm{mM}$ imidazole, elution was done with a linear gradient of $50-400 \mathrm{mM}$ imidazole in buffer A $(5 \mathrm{ml})$. Samples of each fraction $(0.5 \mathrm{ml})$ were analysed by SDS-PAGE and by an activity assay.

Endolysin assays. Endolysin activity was assayed with sterile filtered cleared lysates from induced E. coli cells in comparison with cleared lysates from cells containing pSCodon 1.2 without insert DNA and with fractions from the Ni-NTA chromatography. TBY agar plates were overlaid with $150 \mu$ l overnight culture of the indicator strain in $3 \mathrm{ml}$ top agar $(0.5 \%$ agar in TBY). Drops of endolysin samples were placed onto the surface and plates were incubated at $26{ }^{\circ} \mathrm{C}$. For a rapid screening of many indicator strains these were streaked from a master plate to a fresh TBY plate, and $10 \mu \mathrm{l}$ drops of endolysin samples were layered on the streaks. In addition, the decrease of the $\mathrm{OD}_{600}$ from an exponential phase culture $\left(\mathrm{OD}_{600} \sim 1.0\right)$ after addition of endolysin-containing fractions $\left[20 \mu \mathrm{l}\right.$ extract $\left.(\mathrm{ml} \text { indicator culture })^{-1}\right]$ was monitored at room temperature.

SDS-PAGE and immunoblotting. SDS-PAGE was performed by the method of Laemmli (1970). All gels contained $17.5 \% \quad(w / v)$ acrylamide and were stained with Coomassie brilliant blue R-250. Total cell protein was recovered from induced cells after boiling of the cells in cracking buffer (Lanka \& Barth, 1981).

Immunoblot analysis was done as previously described (DisquéKochem \& Dreiseikelmann, 1997) with a primary monoclonal anti-6His antibody (mouse, Abcam) and a secondary alkaline phosphatase-coupled antibody (goat anti-mouse, Abcam).

Xylem sap collection. Four-week-old tomato plants (S. lycopersicum cv. Moneymaker) were cut about $2 \mathrm{~cm}$ above the ground. The exudates were collected from the stumps for about $30 \mathrm{~min}$.

Bioinformatic analyses. NCBI programs BLASTP, PSI-BLAST (nonredundant database) and Conserved Domains were used for similarity and domain searches of the putative proteins (Altschul et al., 1997). 
For the identification and classification of the peptidase the MEROPS peptidase database (version 8.3) was used (Rawlings et al., 2008). Transmembrane helices were predicted with TMHMM Server v. 2.0 (Krogh et al., 2001).

\section{RESULTS AND DISCUSSION}

\section{Bioinformatic analysis of the putative lys genes of CMP1 and CN77 and their deduced amino acid sequences}

The annotation of a putative endolysin gene on the CMP1 genome (58652 bp; results not shown) was based on several observations. The ORF is located between nucleotides 35449 and 36369 at the end of a cluster of genes that are expressed late in the lytic cycle. The deduced amino acid sequence is 306 aa long with a calculated molecular mass of $34.8 \mathrm{kDa}$. This agrees well with the size of endolysins from other phages that infect Gram-positive bacteria, which have a typical molecular mass of $25-40 \mathrm{kDa}$ (Fischetti, 2008).

Analysis of the amino acid sequence with PSI-BLAST revealed a weak similarity of the N-terminal part to a DDcarboxypeptidase of Stigmatella aurantiaca (identities 29/ 79, 36\%) and Myxococcus xanthus (identities 27/73, 36\%); conserved domains were not indicated. Further analysis with the MEROPS peptidase database revealed that the hypothetical CMP1 endolysin belongs to the M15 family of mostly specialized metalloproteases. The amino acid residues H86, D93, E120 and H123 may represent the active site of a putative zinc metalloprotease. The endolysins of Listeria monocytogenes bacteriophages A118 and A500, which cleave the cell wall peptidoglycan between L-Ala and D-Glu residues, are also members of the M15 peptidase family (Loessner et al., 1995).

The ORF downstream of the putative CMP1 lys gene may encode a small protein of 108 amino acid residues with three predicted transmembrane helices, which strongly indicates that it functions as a class I holin (Young \& Bläsi, 1995). The proximity of the putative holin gene was further evidence that the upstream gene may encode an endolysin, because these two genes that function in the release of progeny phages are mostly clustered at the $3^{\prime}$ end of the late genes. Holins function in the timing of lysis. They are located in the cytoplasmic membrane and are required for the export of the active endolysin at a genetically determined time to allow its access to the peptidoglycan.

The identification of the endolysin gene of bacteriophage CN77 and its deduced amino acid sequence of 290 amino acid residues and a molecular mass of $31.9 \mathrm{kDa}$ was much easier. In contrast to the CMP1 enzyme, PSI-BLAST analysis predicted a highly conserved domain of the VanY superfamily of DD-carboxypeptidases (pfam02557, E-value $4 \mathrm{e}-14)$ for the CN77 endolysin. According to the MEROPS database, the CN77 enzyme also belongs to the M15 family of metalloproteases.
Since the peptidase domains of the CMP1 and CN77 endolysins are located in the $\mathrm{N}$-terminal part of the protein, they may have a modular structure consisting of an $\mathrm{N}$-terminal catalytic domain and a C-terminal substratebinding domain, as described for other endolysins (Garcia et al., 1990; Fischetti, 2008). Neither enzyme showed extensive amino acid sequence similarity to the other. While no similarity was detected between the N-terminal catalytic domains, a moderate similarity was found between the C-terminal binding domains (identities $=39$ / $127 ; 30 \%)$.

\section{Overexpression of the putative lys genes and isolation of the gene products}

The lys PCR products of CMP1 and CN77 were ligated with the vector pSCodon1.2. After transformation of E. coli ArcticExpress with the hybrid plasmids, induction of the cells was performed with $1 \mathrm{mM}$ IPTG for $15 \mathrm{~h}$ at $12{ }^{\circ} \mathrm{C}$ (Fig. 1). The host strain ArcticExpress allowed an efficient folding of proteins after induction at $12{ }^{\circ} \mathrm{C}$ due to the coexpression of the cold-adapted chaperonins Cpn10 and Cpn60 of Oleispira antarctica. Induction with 1 or $0.1 \mathrm{mM}$ IPTG and incubation at 37 and $22{ }^{\circ} \mathrm{C}$ in the absence of the chaperonins resulted in the formation of inclusion bodies (data not shown).

After electrophoretic separation of crude extracts from whole cells in an SDS-polyacrylamide gel, moderate

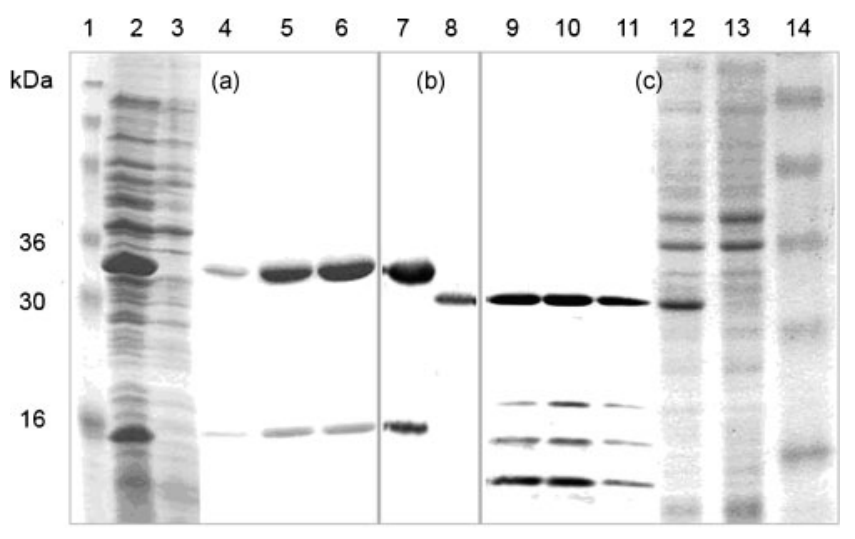

Fig. 1. Overexpression and purification by $17.5 \%$ SDS-PAGE of endolysins from phages CMP1 and CN77. (a) Overexpression and purification of the CMP1 endolysin. Lanes: 1, marker proteins; 2, total protein from induced E. coli pSCodon_Lys_CMP1; 3 , total protein from $E$. coli pSCodon; 4-6, fractions of the His-tagged CMP1 protein from Ni-NTA eluted with a linear imidazole gradient (50-400 mM). (b) Immunoblot analysis: lane 7, total protein from E. coli pSCodon_Lys_CMP1; lane 8, total protein from E. coli pSCodon_Lys_CN77. (c) Overexpression and purification of the CN77 endolysin. Lanes: 9-11, fractions of the His-tagged CN77 protein from Ni-NTA eluted with a linear imidazole gradient (50$400 \mathrm{mM}) ; 12$, total protein from induced E. coli pSCodon_Lys_ CN77; 13 , total protein from E. coli pSCodon; 14 , marker proteins. 
overproduction of proteins corresponding to the calculated molecular mass of the endolysins was visible (Fig. 1a, c). The His-tagged proteins were purified from crude extracts by Ni-NTA chromatography. Fractions of the CMP1 endolysin eluted with imidazole are shown in Fig. 1(a) (lanes 4-6), and those of the CN77 endolysin in Fig. 1(c) (lanes 9-11). The main part of the proteins eluted from the column with 100-200 mM imidazole. The Coomassie bluestained SDS-PAGE showed that the CN77 enzyme was still contaminated with some smaller proteins, but there was only one signal in the immunoblot (Fig. 1b, lane 8). In NiNTA fractions of the CMP1 enzyme only one protein of about $16 \mathrm{kDa}$ could be detected which coeluted with the CMP1 endolysin at about $35 \mathrm{kDa}$. The small protein was already visible as a strong band in the total protein extract of induced cells (Fig. 1a, lane 2). In the immunoblot analysis this protein reacted with the anti-His antibody, suggesting that it was the C-terminal part of the endolysin (Fig. 1b, lane 7). MALDI-TOF analysis confirmed that the larger protein was the endolysin while the smaller one represented the C-terminal part of the enzyme (data not shown).

Examination of the nucleotide sequence of the CMP1 endolysin gene revealed a possible Shine-Dalgarno sequence within the gene four nucleotides upstream from an ATG codon in-frame of the gene (Fig. 2). A hypothetical gene product would consist of the $166 \mathrm{C}$-terminal amino acid residues of the CMP1 endolysin and represent the binding domain of the enzyme. After deletion of an NdeI$M f e I$ DNA fragment from the expression plasmid pSCodon_Lys_CMP1, overproduction of a protein could be observed with a molecular mass corresponding to the small protein that coeluted with the full-length endolysin (data not shown). It is not known whether the speculated translational restart in E. coli also occurs in Clavibacter. Until now there has been no example of the separate expression of a binding domain of an endolysin in addition to the complete enzyme.

\section{Activity of the endolysins}

The enzymic activity of the putative endolysins was assayed by a spot test on agar plates with an indicator strain. Drops of cleared lysates from induced E. coli cultures harbouring the plasmids pSCodon1.2_lys and pSCodon 1.2 were placed on agar plates inoculated with the host strain. Fig. 3 shows the lysis zones on a $\mathrm{Cmm}$ indicator lawn caused by the CMP1 and CN77 endolysins, while the control extract showed no effect. 'Lysis zones' were also obtained with purified protein from the Ni-NTA chromatography (data

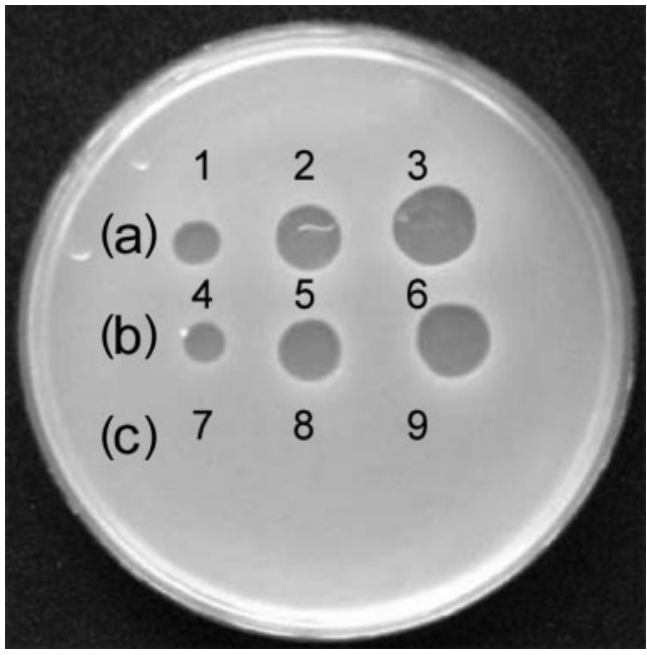

Fig. 3. Activity assay of CMP1 and CN77 endolysins. Extracts of induced $E$. coli cells were spotted on an indicator lawn of $\mathrm{Cmm}$ NCPPB3123. (a) Spots 1-3: 1, 5 and $10 \mu$ of extract from cells with pSCodon1.2_Lys_CMP1; (b) spots 4-6: 1, 5 and $10 \mu \mathrm{l}$ of extract from cells with pSCodon1.2_Lys_CN77; (c) spots 7-9: 1, 5 and $10 \mu \mathrm{l}$ of extract from cells with pSCodon1.2 (control).

not shown). In this assay it cannot be distinguished whether the 'lysis zones' in the bacterial lawns resulted from lysis or from growth inhibition.

To verify the lytic activity of the CMP1 and CN77 proteins, exponential phase cultures of indicator strains $[\mathrm{Cmm}$ NCPPB3123, Cmn NCPPB7173 and C. michiganensis subsp. tessellarius $\left.(\mathrm{Cmt}) \mathrm{NCPPB7295;} \mathrm{OD}_{600} \sim 1\right]$ were exposed to extracts prepared from endolysin-containing $E$. coli cells. Crude extracts were preferred because the purification of the enzymes resulted in a significant loss of activity. The decrease of the optical density in comparison with extracts without endolysin clearly demonstrated that the cells were lysed by the bacteriophage endolysins (Fig. 4). The CMP1 endolysin exhibited the highest efficiency with Cmm cells (Fig. 4a) and the CN77 enzyme with Cmn cells (Fig. 4b), which means that the hosts of the bacteriophages are the optimal substrates. Cmt cells are insensitive to the CMP1 endolysin and are poorly lysed by the CN77 endolysin.

Besides differences in their specificity towards different Clavibacter subspecies the enzymes also showed different $\mathrm{pH}$ optima. While the CMP1 enzyme showed the highest activity at a neutral $\mathrm{pH}$ of about 7 , the CN77 enzyme had a $\mathrm{pH}$ optimum of about 8-9 (Fig. 5). Both enzymes showed

\section{Mfel} ....GCA ATT GAT TGG TCT CTT TTG GAG GAT AAC ATG...

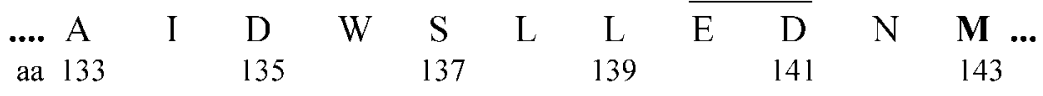

Fig. 2. Part of the CMP1 endolysin gene with a hypothetical ribosome-binding site (RBS) and a possible ATG start codon in-frame with the gene. 
(a)

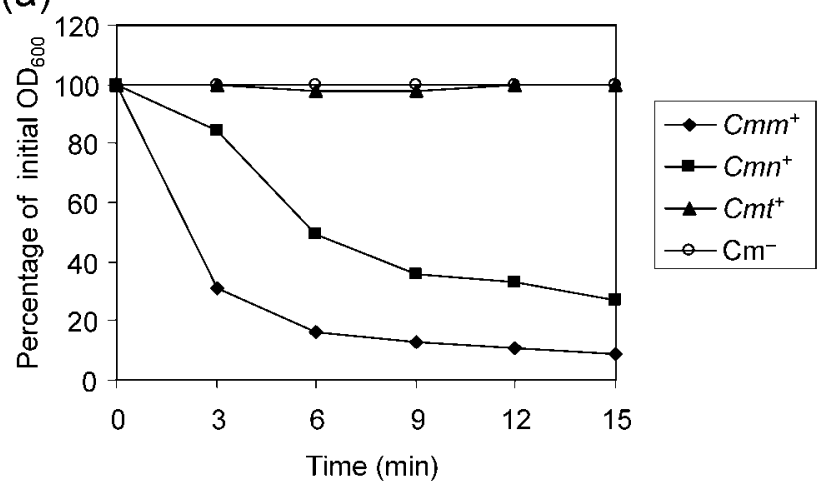

(b)

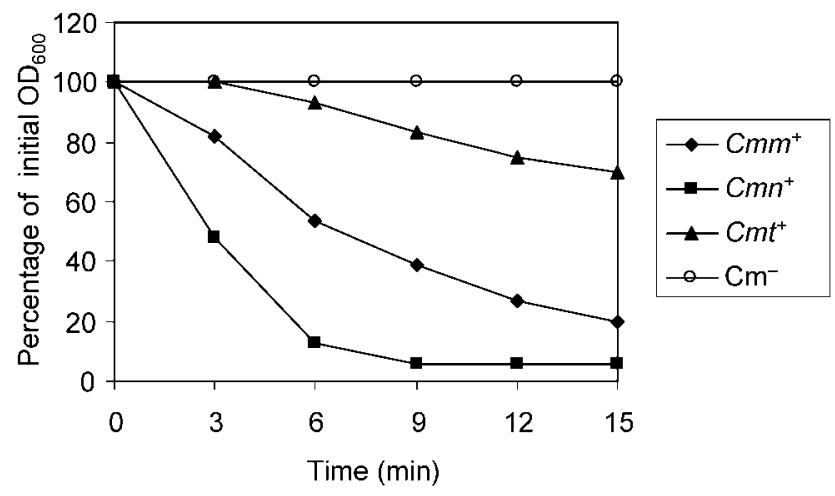

Fig. 4. Lysis of different Clavibacter strains by CMP1 (a) and CN77 (b) endolysins. A $20 \mu \mathrm{l}$ volume of crude extract from induced cells expressing the lysin was added to $1 \mathrm{ml}$ of a culture of $\mathrm{Cmm} \mathrm{NCPPB} 123(\boldsymbol{)}), \mathrm{Cmn} \mathrm{NCPPB7173}(\boldsymbol{\square})$ and $\mathrm{Cmt}$ NCPPB7295 (A) (in TBY medium, initial OD $_{600} \sim 1.0$ ). As a negative control, crude extracts from induced cells without endolysin genes were added to the cultures $\left(\mathrm{Cm}^{-} ; \bigcirc\right)$. The decrease in $\mathrm{OD}_{600}$ was monitored every $3 \mathrm{~min}$ for $15 \mathrm{~min}$.

significant activities in slightly acidic buffers between $\mathrm{pH} 5$ and 7.

Activity in an acidic milieu is a prerequisite for the use of the CMP1 endolysin produced from a transgenic tomato plant for protection against Clavibacter infections, as the $\mathrm{pH}$ of the tomato xylem fluid is about 5.5-6.0 (White et al., 1981). To analyse whether the CMP1 endolysin is active in xylem sap, Cmm cells were sedimented and resuspended in freshly prepared xylem sap from 4 -week-old tomato plants. After addition of the enzyme-containing extract, the decrease in $\mathrm{OD}_{600}$ was monitored (Fig. 6). The enzyme was active in xylem sap, but the activity was reduced in comparison with the activity in buffer at $\mathrm{pH} 5.7$, the $\mathrm{pH}$ determined for xylem sap.

\section{Host specificity of CMP1 and CN77 endolysins}

Assuming a future application of the endolysins in plant protection it is necessary to determine the host specificity.

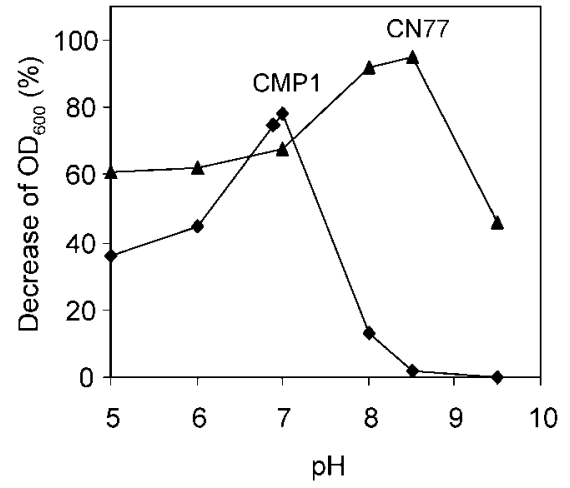

Fig. 5. Activity of CMP1 and CN77 endolysins depending on the $\mathrm{pH}$ of the reaction mixture. A $1 \mathrm{ml}$ volume of indicator cells $(\mathrm{Cmm}$ NCPPB3123 for CMP1 endolysin, Cmn NCPPB7173 for CN77 endolysin) at initial $\mathrm{OD}_{600} \sim 1.0$ was sedimented by centrifugation and resuspended in $1 \mathrm{ml} 50 \mathrm{mM}$ Tris/ $\mathrm{HCl}$ of various $\mathrm{pHs}, 50 \mathrm{mM}$ $\mathrm{NaCl}, 5 \mathrm{mM} \beta$-mercaptoethanol. A $20 \mu$ l volume of crude lysate from induced cells expressing the lysins was added. The decrease in $\mathrm{OD}_{600}$ was monitored every $3 \mathrm{~min}$ for $15 \mathrm{~min}$. The figure shows the amount of lysed cells 6 min after the addition of the enzymes.

For ecological reasons an enzyme with a high degree of specificity would be preferred. In summary, 46 strains with different cell wall types were screened for lysis after spotting a CMP1 and CN77 endolysin-containing extract onto streaks of the strains on agar plates. All strains are listed in Supplementary Table S1 and the most important ones in Table 1. All five subspecies of C. michiganensis were lysed by the endolysins, with the exception of the subspecies tessellarius, which was not lysed by CMP1

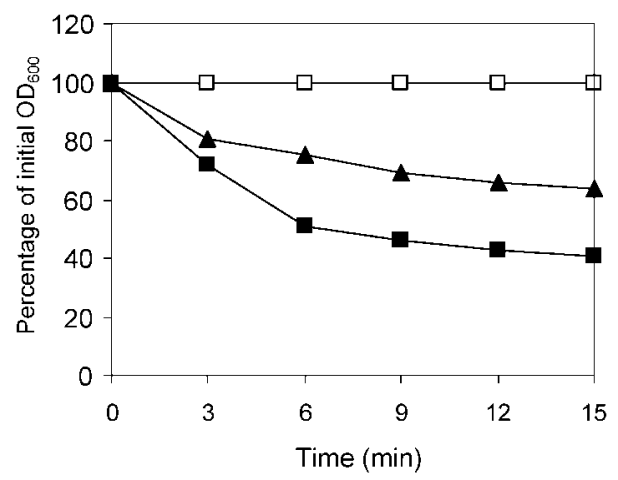

Fig. 6. Activity of CMP1 endolysin in xylem sap. A $1 \mathrm{ml}$ volume of indicator cells ( $\mathrm{Cmm}$ NCPPB3123) with initial $\mathrm{OD}_{600} \sim 1.0$ was sedimented by centrifugation and resuspended in $1 \mathrm{ml} 50 \mathrm{mM}$ Tris $/ \mathrm{HCl}, \mathrm{pH}$ 5.7, $50 \mathrm{mM} \mathrm{NaCl}, 5 \mathrm{mM} \beta$-mercaptoethanol (ם) or freshly prepared xylem sap (A). A $20 \mu$ l volume of crude lysate from induced cells expressing the lysins was added. The decrease in $\mathrm{OD}_{600}$ was monitored every $3 \mathrm{~min}$ for $15 \mathrm{~min}$. The figure shows the amount of lysed cells 6 min after the addition of the enzymes. As a control, $\mathrm{OD}_{600}$ was determined for cells without addition of endolysin ( $\square$ ). 
Table 1. Lysis assay with CMP1 endolysin on different Microbacteriaceae strains

\begin{tabular}{|c|c|c|c|}
\hline Strain & $\begin{array}{c}\text { Lysis by CMP1 } \\
\text { endolysin }\end{array}$ & $\begin{array}{c}\text { Lysis by CN77 } \\
\text { endolysin }\end{array}$ & Murein type \\
\hline C. michiganensis subsp. michiganensis NCPPB3123 & + & + & $\mathrm{B} 2 \gamma(\mathrm{D}-$ and $\mathrm{L}-\mathrm{DAB})$ \\
\hline C. michiganensis subsp. nebraskensis NCPPB2579 & + & + & \\
\hline C. michiganensis subsp. sepedonicus CS7 (Laine et al., 1996) & + & + & \\
\hline C.michiganensis subsp. insidiosus NCPPB1109 & + & + & \\
\hline C. michiganensis subsp. tessellarius LMG7295 & - & - & \\
\hline L. aquatica DSM20146 & - & - & $\mathrm{B} 2 \gamma(\mathrm{D}-$ and $\mathrm{L}-\mathrm{DAB})$ \\
\hline Rathayibacter iranicus NCPPB 2253 & - & - & $\mathrm{B} 2 \gamma(\mathrm{L}-\mathrm{DAB})$ \\
\hline Rathayibacter rathayi NCPPB 2980 & - & - & \\
\hline Rathayibacter tritici NCPPB 1857 & - & - & \\
\hline Okibacterium sp.* & - & - & $\mathrm{B} 2 \alpha$ \\
\hline Curtobacterium sp.* & - & - & \\
\hline
\end{tabular}

*Environmental isolates (K.-H. Gartemann, Universität Bielefeld, Germany).

endolysin (as shown in Fig. 4). The cell wall of the species C. michiganensis has been determined to be type $\mathrm{B} 2 \gamma$, which contains D- and L-2,4-DAB as a diamino acid (Sasaki et al., 1998; Schleifer \& Kandler, 1972). So far, there is no information on whether the murein type of the subspecies tessellarius differs from that of the other subspecies. The determination of the enzyme cleavage site would help us to learn more about the structure of the peptidoglycan of the C. michiganensis subspecies. To show that the enzymes lyse different $\mathrm{Cmm}$ strains, 11 environmental $\mathrm{Cmm}$ isolates from Germany and Israel (not shown in Supplementary Table S1) were tested and were lysed by both enzymes, demonstrating that the enzymes are generally active towards $\mathrm{Cmm}$. The same result was obtained with $\mathrm{Cmn}$ strains. Besides the CN77 host strain Her1088, nine additional Cmn strains from the NCPPB colllection were screened. All strains were lysed by the CMP1 and CN77 endolysins.

As far as is known, the only other species with the same peptidoglycan type as Clavibacter, type B $2 \gamma$, containing Dand L-DAB, are members of the genus Leifsonia (Evtushenko et al., 2000). Nevertheless Leifsonia aquatica was not lysed by the endolysins of phages CMP1 and CN77. This suggests that the peptidoglycans of Clavibacter and Leifsonia are not identical but may contain some minor modifications not yet determined. Further species closely related to $C$. michiganensis, such as the plant pathogen Rathayibacter sp., which was separated from the Clavibacter group several years ago, are not affected by the enzyme (Sasaki et al., 1998). Like Clavibacter, the genus Rathayibacter has a peptidoglycan of type B2 $\gamma$, but it contains only L-DAB. Five environmental isolates which were classified in different genera of the Microbacteriaceae were also not lysed by the endolysins. They have different peptidoglycan types such as $\mathrm{B} 2 \alpha, \mathrm{B} 2 \beta$ and $\mathrm{B} 1 \alpha$ (Table 1). Therefore, it was not surprising that Gram-positive strains such as Bacillus subtilis, Bacillus megaterium, Enterococcus faecalis, Staphylococcus aureus, Micrococcus luteus and Corynebacterium glutamicum, which all have a type A peptidoglycan (cross-linkage between position 3 and position 4 of the adjacent peptide; Schleifer \& Kandler, 1972), and Gram-negative strains were not affected by the enzymes. Thus, the activity of the bacteriophage CMP1 and CN77 endolysins is limited to $C$. michiganensis subspecies and they do not even lyse other related species of the Microbacteriaceae.

In this communication we demonstrate that the products of the lys genes from bacteriophages CMP1 and CN77 encode active and highly specific endolysins. The enzymes lyse strains of $C$. michiganensis from the outside by hydrolysis of the murein sacculus. This renders the bacterial cells osmotically unstable and finally leads to cell death. So far we have not found any Gram-negative or Gram-positive bacterium other than C. michiganensis that is lysed by the enzymes, underlining the specificity of the enzymes for the type B2 $\gamma$ cell wall. Thus, the application of these enzymes in biocontrol of $\mathrm{Cmm}$ would be unlikely to affect the bacterial community in the soil or other bacteria associated with the plant, which may have a beneficial effect on plant growth. In the next step of this project we plan to express the endolysins in tomato plants.

Infection of tomato plants usually occurs by wounds in the root or stem section of the plant. Therefore, the spread of infection is particularly caused by the pruning of tomato plants. A tomato plant that expresses the endolysin may 
inhibit the invasion of $\mathrm{Cmm}$ into the wounded tissue and thus may prevent a successful infection by $\mathrm{Cmm}$.

\section{ACKNOWLEDGEMENTS}

We thank S. Manulis-Sasson, ARO, Bet Dagan, Israel, and K. H. Gartemann, Universität Bielefeld, Germany, for providing us with strains from their collections.

\section{REFERENCES}

Altschul, S. F., Madden, T. L., Schäffer, A. A., Zhang, J., Zhang, Z., Miller, W. \& Lipman, D. J. (1997). Gapped BLAST and PSI-BLAST: a new generation of protein database search programs. Nucleic Acids Res 25, 3389-3402.

Balogh, B. \& Jones, J. B. (2003). Improved efficacy of newly formulated bacteriophages for management of bacterial spot on tomato. Plant Dis 87, 949-954.

Beilstein, F. \& Dreiseikelmann, B. (2006). Bacteriophages of freshwater Brevundimonas vesicularis isolates. Res Microbiol 157, 213-219.

Cook, F. D. \& Katznelson, H. (1960). Isolation of bacteriophages for the detection of Corynebacterium insidiosum, agent of bacterial wilt of alfalfa. Can J Microbiol 6, 121-126.

Davis, M. J., Gillespie, A. G., Jr, Vidaver, A. K. \& Harris, R. W. (1984). Clavibacter: a new genus containing some phytopathogenic coryneform bacteria, including Clavibacter xyli subsp. xyli sp. nov., subsp. nov. and Clavibacter xyli subsp. cynodontis subsp. nov., pathogens that cause ratoon stunting disease of sugarcane and bermudagrass stunting disease. Int J Syst Bacteriol 34, 107-117.

Disqué-Kochem, C. \& Dreiseikelmann, B. (1997). The cytoplasmic DNA-binding protein TraM binds to the inner membrane protein TraD in vitro. $J$ Bacteriol 179, 6133-6137.

Eayre, C. G., Concelmo, D. E. \& Bartz, J. A. (1990). Control of soft rot Erwinias with bacteriophages. Phytopathology 80, 994.

Echandi, E. \& Sun, M. (1973). Isolation and characterization of a bacteriophage for the identification of Corynebacterium michiganense. Phytopathology 63, 1401-1403.

Eichenlaub, R., Gartemann, K.-H. \& Burger, A. (2007). Clavibacter michiganensis, a group of Gram-positive pathogenic bacteria. In PlantAssociated Bacteria, pp. 383-422. Edited by S. S. Gnanamanickam. Dordrecht: Springer.

Evtushenko, L. I., Dorofeeva, L. V., Subbotin, S. A., James, R., Cole, J. R. \& Tiedje, J. M. (2000). Leifsonia poae gen. nov., sp. nov., isolated from nematode galls on Poa annua, and reclassification of 'Corynebacterium aquaticum ' Leifson 1962 as Leifsonia aquatica (ex Leifson 1962) gen. nov., nom. rev., comb. nov. and Clavibacter xyli Davis et al. 1984 with two subspecies as Leifsonia xyli (Davis et al. 1984) gen. nov., comb. nov. Int J Syst Evol Microbiol 50, 371380.

Fischetti, V. A. (2008). Bacteriophage lysins as effective antibacterials. Curr Opin Microbiol 11, 393-400.

Garcia, P., Garcia, J. L., Garcia, E., Sanchez-Puelles, J. M. \& Lopez, R. (1990). Modular organization of the lytic enzymes of Streptococcus pneumoniae and its bacteriophages. Gene 86, 81-88.

Jones, J. B., Jackson, L. E., Balogh, B., Obradovic, A., Iriarte, F. B. \& Momol, M. T. (2007). Bacteriophages for plant disease control. Annu Rev Phytopathol 45, 245-262.

Kleitman, F., Barash, I., Burger, A., Iraki, N., Falah, Y., Sessa, G., Weinthal, D., Chalupowicz, L., Gartemann, K.-H. \& other authors
(2008). Characterization of a Clavibacter michiganensis subsp. michiganensis population in Israel. Eur J Plant Pathol 121, 463475.

Krogh, A., Larsson, B., von Heijne, G. \& Sonnhammer, E. L. L. (2001). Predicting transmembrane protein topology with a hidden Markov model: application to complete genomes. J Mol Biol 305, 567-580.

Laemmli, U. K. (1970). Cleavage of structural proteins during the assembly of the head of bacteriophage T4. Nature 227, 680-685.

Laine, M. J., Nakhei, H., Dreier, J., Lehtila, K., Meletzus, D., Eichenlaub, R. \& Metzler, M. C. (1996). Stable transformation of the Gram-positive phytopathogenic bacterium Clavibacter michiganensis subsp. sepedonicus. Appl Environ Microbiol 62, 1500-1506.

Lanka, E. \& Barth, P. T. (1981). Plasmid RP4 specifies a deoxyribonucleic acid primase involved in its conjugal transfer and maintenance. J Bacteriol 148, 769-781.

Lee, I.-M., Batoszyk, I. M., Gundersen-Rindal, D. E. \& Davis, R. E. (1997). Phylogeny and classification of bacteria in the genera Clavibacter and Rathayibacter on the basis of 16S rRNA gene sequence analyses. Appl Environ Microbiol 63, 2631-2636.

Loessner, M. J. (2005). Bacteriophage endolysins - current state of research and applications. Curr Opin Microbiol 8, 480-487.

Loessner, M. J., Wendlinger, G. \& Scherer, S. (1995). Heterogeneous endolysins in Listeria monocytogenes bacteriophages: a new class of enzymes and evidence for conserved holin genes within siphoviral lysis cassettes. Mol Microbiol 16, 1231-1241.

Parisien, A., Allain, B., Zhang, J., Mandeville, R. \& Lan, C. Q. (2008). Novel alternatives to antibiotics: bacteriophages, bacterial cell wall hydrolases, and antimicrobial peptides. J Appl Microbiol 104, $1-13$.

Park, Y.-H., Suzuki, K.-I., Yim, D.-G., Lee, K.-C., Kim, E., Yoon, J.-S., Kim, S.-J., Kho, Y.-H., Goodfellow, M. \& Komogata, K. (1993). Suprageneric classification of peptidoglycan group B actinomycetes by nucleotide sequencing of $5 \mathrm{~S}$ ribosomal RNA. Antonie Van Leeuwenhoek 64, 307-313.

Rawlings, N. D., Morton, F. R., Kok, C. Y., Kong, J. \& Barrett, A. J. (2008). MEROPS: the peptidase database. Nucleic Acids Res 36 (Database issue), D320-D325.

Sasaki, J., Chijimatsu, M. \& Suzuki, K. (1998). Taxonomic significance of 2,4-diaminobutyric acid isomers in the cell wall peptidoglycan of actinomycetes and reclassification of Clavibacter toxicus as Rathayibacter toxicus comb. nov. Int J Syst Bacteriol 48, 403410.

Schleifer, K.-H. \& Kandler, O. (1972). Peptidoglycan types of bacterial cell walls and their taxonomic implications. Bacteriol Rev 36, 407477.

Schnabel, E. L., Fernando, W. G. D., Jackson, L. L., Meyer, M. P. \& Jones, A. L. (1998). Bacteriophages of Erwinia amylovora and their potential in biocontrol. Appl Environ Microbiol 68, 1122-1131.

Shirako, Y., Vidaver, A. K. \& Ackermann, H. W. (1986). Partial characterization of bacteriophages for Clavibacter michiganense subsp. nebraskense. Ann Phytopathol Soc Jpn 52, 793-800.

Strider, D. L. 1969. Bacterial Canker of Tomato Caused by Corynebacterium michiganense. A Literature Review and Bibliography. North Carolina Agric. Exp. Sta., Tech. Bull. no. 193.

Sulakvelidze, A. \& Barrow, P. (2005). Phage therapy in animals and agribusiness. In Bacteriophages: Biology and Applications, pp. 335-380. Edited by E. Kutter \& A. Sulakvelidze. Boca Raton, FL: CRC Press.

Sulakvelidze, A. \& Kutter, E. (2005). Bacteriophage therapy in humans. In Bacteriophages: Biology and Applications, pp. 381-436. Edited by E. Kutter \& A. Sulakvelidze. Boca Raton, FL: CRC Press. 
Tanaka, H., Negishi, H. \& Maeda, H. (1990). Control of tobacco bacterial wilt by an avirulent strain of Pseudomonas solanacearum M4S and its bacteriophage. Ann Phytopathol Soc Jpn 56, 243246.

Vidaver, A. K., Gross, D. C., Wysong, D. S. \& Doupnik, B. L. (1981). Diversity of Corynebacterium nebraskense strains causing Goss's bacterial wilt and blight of corn. Plant Dis 65, 480-482.
White, M. C., Decker, A. M. \& Chaney, R. L. (1981). Metal complexation in xylem fluid. I. Chemical composition of tomato and soybean stem exudate. Plant Physiol 67, 292-300.

Young, R. \& Bläsi, U. (1995). Holins: form and function in bacteriophage lysis. FEMS Microbiol Rev 17, 191-205.

Edited by: P. R. Herron 